\title{
Involvement of Gaba and Cannabinoid Receptors in Central Food Intake Regulation in Neonatal Layer Chicks: Role of $\mathrm{CB}_{1}$ and $\mathrm{GABA}_{A}$ Receptors
}

\section{-Author(s)}

\section{Zendehdel $\mathrm{M}$}

Tirgari F"

Shohre B"

Deldar $\mathrm{H}^{\prime \prime}$

Hassanpour S"II

Department of Basic Sciences, Faculty of Veterinary Medicine, University of Tehran, 14155-6453, Tehran, Iran

" Department of Animal Science, Sari Agricultural Sciences \& Natural Resources University, Sari, Iran

III Department of Basic Sciences, Faculty of Veterinary Medicine, Science and Research Branch, Islamic Azad University, Tehran, Iran

\section{Mail Address}

Corresponding author e-mail address Morteza Zendehdel

Department of Basic Sciences, Faculty of Veterinary Medicine, University of Tehran,

14155-6453, Tehran, Iran

Tel: $\quad$ +98-21-61117186

Email: zendedel@ut.ac.ir

\section{-Keywords}

Cannabinoidergic, GABAergic, Food intake, Layer-type chicken.

\section{ABSTRACT}

Feeding behavior is regulated via a complex network which interacts via diverse signals from central and peripheral tissues. Endocannabinoids modulate release of GABA in a variety of regions of the central nervous system. Endocannabinoids and GABAergic system have an important role in the central regulation of appetite. Thus, the present study examines the possible interaction of central canabinoidergic and GABAergic systems on food intake in 3-h food-deprived $\left(\mathrm{FD}_{3}\right)$ neonatal layer-type chicks. The results of this study showed that intracerebroventricular (ICV) injection of 2-AG (2-Arachidonoylglycerol, selective $C_{1}$, receptors agonist, $2 \mu \mathrm{g}$ ) significantly increased food intake and this effect of 2-AG was attenuated by Picrotoxin $\left(G_{A B A}\right.$ antagonist, $\left.0.5 \mu \mathrm{g}\right)(\mathrm{P}<0.001)$; but $21 \mathrm{ng}$ CGP54626 (GABA $A_{B}$ antagonist) had no effect ( $p>0.05$ ). Also, hyperphagic effect of $\mathrm{CB} 65\left(\mathrm{CB}_{2}\right.$ receptors agonist, $\left.1.25 \mu \mathrm{g}\right)$ was not affected by Picrotoxin or CGP54626 ( $p>0.05$ ). Moreover, the food intake of chicks was significantly increased by ICV injection of GABA agonist (Gaboxadol, $0.2 \mu \mathrm{g}$ ) and SR141716A (CB, receptors antagonist, $6.25 \mu \mathrm{g})$ significantly decreased Gaboxadol-induced hyperphagia $(P<0.001)$ but $C B_{2}$ receptors antagonist $(A M 630,1.25 \mu \mathrm{g})$ had no effect. In contrast, co-injection of SR141716A or AM630 with GABA agonist (baclofen, $0.2 \mu \mathrm{g}$ ) had no effect on the hyperphagia induced by baclofen ( $p>0.05)$. These data showed there might be an interaction between central cannabinoidergic and GABAergic systems via $C_{1}$ and $G_{A B A}$ receptors in control of food intake in neonatal layer chicks.

\section{INTRODUCTION}

Feeding behavior is a complex physiologic phenomenon which interacts via various signals from central and peripheral tissues. In the central nervous system (CNS), several neurotransmitters interact by a wide distributed neurological network on food intake regulation (Zendehdel et al., 2014; Honda, 2016). $\gamma$-aminobutyric acid (GABA) is one of the most abundant neurotransmitter in mammalian brain. The GABAergic is known as an inhibitory neurotransmitter in the CNS (Bonaventura et al., 2012). GABA exerts its effect via two distinct receptors including the bicuculline-sensitive $G A B A_{A}$ receptor and the bicuculline-insensitive $G_{A B A_{B}}$ receptors (Stratford and Wirtshafter, 2013). The $G A B A_{A}$ and $G A B A_{C}$ receptors are part of a macromolecular complex coupled to a $\mathrm{Cl}^{-}$ionophore while $\mathrm{GABA}_{B}$ is metabotropic receptor belong to G-protein coupled receptors (GPCRs) (Jonaidi et al., 2012).

The appetite-stimulating effects of marijuana (Cannabis sativa) are known in science for the past decades. Animal tissues express at least two cannabinoidergic (CBergic) receptors: cannabinoid type 1 $\left(C B_{1}\right)$ and type $2\left(C_{2}\right)$ receptors which belong to the GPCRs (Kangas 
et al., 2013). CB receptors mainly expressed in the presynaptic terminals of the brain (Sharkey et al., 2014) and $C_{2}$ receptors formerly exist on cells and organs of the immune system in the peripheral nervous system (PNS) but they also expressed in the CNS (Onaivi et al., 2008). The endocannabinoids (ECBs) mediates many physiological functions like pain relief, motor control, learning and memory formation as well as appetite regulation (D'Addario et al., 2014).

GABA and CBs involved control of food intake (Volkow et al., 2011). It appears GABA has orexigenic effect in domestic fowls (Jonaidi et al., 2012). ICV injection of Muscimol (a GABA $A_{A}$ agonist) and Baclofen (a $G_{A B A}$ agonist) increased food consumption in rats (Ebenezer, 1990), turkeys (Denbow, 1991), meat-type (broiler) and layer-type chicks (hens) (Jonaidi et al., 2002). Both $C B_{1}$ and $C B_{2}$ receptors have a role in food intake regulation in the rat (Chen et al., 2006). Scarce information exists about the role of ECBs on feeding behavior in domestic fowl. Reports claim just $\mathrm{CB}_{1}$ receptors have a regulatory role on appetite in broilers (et al., 2011; Novoseletsky et al., 2011). Recent reports revealed both $C B_{1}$ and $C B_{2}$ receptors have hyperphagic effect in neonatal layer-type chicken (Alizadeh et al., 2015; Hassanpour et al., 2015).

There is central evidence mechanisms for food intake regulation are different between mammalian and birds (Zendehdel \& Hassanpour 2014). Comparative physiological studies suggested there are differences award pathways between the meat-type and layertype chicks (Alizadeh et al., 2015). For example, food intake mediates via both $C B_{1}$ and $C B_{2}$ receptors in layer-type chicken (Alizadeh et al., 2015) but only $C_{2}$ receptors interact on feeding in meat-type chicken (Emadi et al., 2011; Novoseletsky et al., 2011). For instance, ICV injection of Baclofen had no effect on food intake in broilers (Jonaidi et al., 2002; Tajalli et al., 2006; Zendehdel et al., 2008, 2009).

During the last several years, GABA and ECBs have been the subject of an increasing number of behavioral studies. Several types of researches are done to find the mediatory effect of neurotransmitters on feeding behavior in mammals but aspects of food intake regulation in avian are still unclear (Zendehdel \& Hassanpour, 2014). ECBs modulate the release of GABA in a variety of regions of the CNS, including the hippocampus, basal ganglia, cerebellum, and brainstem. Anatomical investigations have shown high levels of $C B_{1}$ receptor immune-reactivity and mRNA associated with GABAergic neurons (Irving et al., 2002). In the brain, $C_{1}$ receptors is predominantly expressed presynaptically and modulating the release of neurotransmitters, such as GABA, dopamine, noradrenaline, glutamate and serotonin (Cota et al., 2003). To the best of our knowledge, no report exists on the interconnection of the CBergic and GABAergic systems on food intake regulation and energy balance in neonatal layer type chicken. So, the aim of this study was to investigate the possible involvement of the CBergic and GABAergic systems on feeding behavior in $3 \mathrm{~h}$ food deprived $\left(\mathrm{FD}_{3}\right)$ neonatal layer type chicken.

\section{MATERIALS AND METHODS}

\section{Animals}

In this study, a total 384 one-day-old layer-type chickens (Hy-Line) purchased from a local hatchery (Morghak Co. Iran). Birds were kept as flocks for two days then randomly transferred into individual cages at a temperature of $30 \pm 1^{\circ} \mathrm{C}$ with $50 \pm 2$ percent humidity (Olanrewaju et al., 2006). A commercial diet provided during the study containing $21 \%$ crude protein and $2850 \mathrm{kcal} / \mathrm{kg}$ of metabolizable energy (Chineh Co. Iran). All birds received ad libitum food and fresh water during the study. Just three h prior the ICV injections, chicken, were food deprived $\left(\mathrm{FD}_{3}\right)$ but had free access to water. The injections were applied to all birds at five days of age. Animal handling and experimental procedures were performed according to the Guide for the Care and Use of Laboratory animals by the National Institutes of Health (USA) and the current laws of the Iranian government for animal care.

\section{Experimental Drugs}

Gaboxadol (GABA $A_{A}$ agonist), Baclofen (GABA agonist), Picrotoxin (GABA antagonist), CGP54626 $\left(G A B A_{B}\right.$ antagonist), 2-AG (2-Arachidonoylglycerol, a selective $C B_{1}$ receptors agonist), $C B 65$ (a selective $C B_{2}$ receptors agonist), SR141716A (a selective $C B_{1}$ receptors antagonist), $A M 630$ (a selective $C_{2}$ receptors antagonist) and Evans Blue purchased from Sigma Co. (Sigma, USA). Drugs except 2-AG at first dissolved in absolute dimethyl sulfoxide (DMSO) then diluted with $0.85 \%$ saline containing Evans blue at a ratio of 1/250. 2-AG solved in $0.1 \%$ Evans blue solution which was prepared in $0.85 \%$ saline. DMSO with this ratio does not have a cytotoxic effect (Blevins et al., 2002; Qi et al., 2008).

\section{ICV injection procedures}

In this study, eight experiments designed to investigate interconnection of CBergic and GABAergic systems on cumulative food intake in neonatal layertype birds (each includes four groups within 12 
replicates in each group). Before each treatment, the chicks were weighed and based on their body weight allocated into groups so the average weight between treatment groups was as uniform as possible. ICV injection was applied using a microsyringe (Hamilton, Switzerland) without anesthesia according to the technique previously described by Davis et al., (1979) and Furuse et al., (1997) in which the head of the birds was held with an acrylic device while the bill holder was $45^{\circ}$ and calvarium parallel to the surface of table (Van Tienhoven and Juhasz, 1962). In a plate, a hole was drilled in the skull over the right lateral ventricle and immediately overlaid through this plate. A microsyringe inserted into the right ventricle via the hole and tip of the needle penetrated $4 \mathrm{~mm}$ beneath the skin of the skull. It is revealed that there is no injection-induced physiological stress using this method in neonatal chicks (Saito et al., 2005). Each bird received an ICV injection (with vehicle or drug solution) in a volume of $10 \mu \mathrm{L}$. Right away after the injection, $\mathrm{FD}_{3}$ birds returned to their individual cages and offered fresh water and food (pre-weighed). Cumulative food intake (gr) was measured at 30,60 and 120 min after the injection. Food consumption was calculated as a percentage of body weight to minimize the effect of body weight on the amount of food intake. Each bird was just used once in each experimental group. At the end, accuracy of placement of the injection in the ventricle was verified by the presence of Evans Blue followed by slicing the frozen brain tissue. In each group, 12 birds received the injection, but just data of those individuals where the dye was present in their lateral ventricle (12 chickens per group), was used for the analysis. All experimental procedures were done from 8:00 A.M. until 3:30 P.M. Also, the time course for feeding behavior was selected by previous studies (Jonaidi et al., 2012; Zendehdel \& Hassanpour 2014; Alimohammadi et al., 2015; Alizadeh et al., 2015; Hassanpour et al., 2015).

\section{Feeding experiments}

In this study, eight experiments were designed, each with four treatment groups: A, B, C and D groups ( $n=48$ in each). In experiment 1 , chickens received intracerebroventricular (ICV) injection of (A) saline, (B) 2-AG (2-Arachidonoylglycerol, selective $C B$, receptors agonist, $2 \mu \mathrm{g}),(\mathrm{C})$ Picrotoxin $\left(\mathrm{GABA}_{\mathrm{A}}\right.$ antagonist, $0.5 \mu \mathrm{g})$ and $(\mathrm{D})$ co-injection of $2-A G+$ Picrotoxin. In experiment 2, birds injected with $(A)$ saline, $(B)$ 2-AG $(2 \mu \mathrm{g}),(\mathrm{C})$ CGP54626 (GABA ${ }_{\mathrm{B}}$ antagonist, 21ng) and (D) co-injection of 2-AG+CGP54626. In experiment 3, animals received: (A) saline, (B) CB65 (selective
$\mathrm{CB}_{2}$ receptors agonist, $\left.1.25 \mu \mathrm{g}\right),(\mathrm{C})$ Picrotoxin $(0.5 \mu \mathrm{g})$ and (D) CB65+ Picrotoxin. In experiment four, chicks

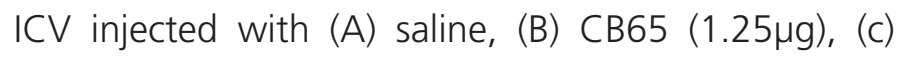

Table 1 - Treatments procedure in experiments 1-8

\begin{tabular}{|c|c|}
\hline $\begin{array}{l}\text { Exp. } 1 \\
\text { Treatment groups }\end{array}$ & ICV Injection \\
\hline A & $\mathrm{CS}^{*}$ \\
\hline B & $2-A G(2 \mu g)$ \\
\hline C & Picrotoxin $(0.5 \mu \mathrm{g})$ \\
\hline $\mathrm{D}$ & $2-A G(2 \mu g)+$ Picrotoxin $(0.5 \mu \mathrm{g})$ \\
\hline $\begin{array}{l}\text { Exp. } 2 \\
\text { Treatment groups }\end{array}$ & ICV Injection \\
\hline A & CS* \\
\hline B & $2-A G(2 \mu g)$ \\
\hline C & CGP54626 (21ng) \\
\hline $\mathrm{D}$ & $2-A G(2 \mu g)+C G P 54626(21 n g)$ \\
\hline $\begin{array}{l}\text { Exp. } 3 \\
\text { Treatment groups }\end{array}$ & ICV Injection \\
\hline A & $\mathrm{CS}^{*}$ \\
\hline B & CB65 $(1.25 \mu \mathrm{g})$ \\
\hline C & Picrotoxin $(0.5 \mu \mathrm{g})$ \\
\hline $\mathrm{D}$ & CB65 $(1.25 \mu \mathrm{g})+$ Picrotoxin $(0.5 \mu \mathrm{g})$ \\
\hline $\begin{array}{l}\text { Exp. } 4 \\
\text { Treatment groups }\end{array}$ & ICV Injection \\
\hline A & $\mathrm{CS}^{*}$ \\
\hline B & CB65 $(1.25 \mu \mathrm{g})$ \\
\hline C & CGP54626 (21ng) \\
\hline $\mathrm{D}$ & CB65 $(1.25 \mu \mathrm{g})+\mathrm{CGP} 54626(21 \mathrm{ng})$ \\
\hline $\begin{array}{l}\text { Exp. } 5 \\
\text { Treatment groups }\end{array}$ & ICV Injection \\
\hline A & $C S$ * \\
\hline B & Gaboxadol $(0.2 \mu \mathrm{g})$ \\
\hline C & SR141716A $(6.25 \mu \mathrm{g})$ \\
\hline $\mathrm{D}$ & Gaboxadol $(0.2 \mu \mathrm{g})+$ SR141716A $(6.25 \mu \mathrm{g})$ \\
\hline $\begin{array}{l}\text { Exp. } 6 \\
\text { Treatment groups }\end{array}$ & ICV Injection \\
\hline A & $C S$ * \\
\hline B & Gaboxadol $(0.2 \mu \mathrm{g})$ \\
\hline C & AM630 $(1.25 \mu \mathrm{g})$ \\
\hline $\mathrm{D}$ & Gaboxadol $(0.2 \mu \mathrm{g})+$ AM630 $(1.25 \mu \mathrm{g})$ \\
\hline $\begin{array}{l}\text { Exp. } 7 \\
\text { Treatment groups }\end{array}$ & ICV Injection \\
\hline A & $C S$ * \\
\hline B & baclofen $(0.2 \mu \mathrm{g})$ \\
\hline C & SR141716A $(6.25 \mu \mathrm{g})$ \\
\hline $\mathrm{D}$ & baclofen $(0.2 \mu \mathrm{g})+$ SR141716A $(6.25 \mu \mathrm{g})$ \\
\hline $\begin{array}{l}\text { Exp. } 8 \\
\text { Treatment groups }\end{array}$ & ICV Injection \\
\hline A & $C S^{*}$ \\
\hline B & baclofen $(0.2 \mu \mathrm{g})$ \\
\hline C & AM630 $(1.25 \mu \mathrm{g})$ \\
\hline $\mathrm{D}$ & baclofen $(0.2 \mu \mathrm{g})+\mathrm{AM} 630(1.25 \mu \mathrm{g})$ \\
\hline
\end{tabular}

CS: control solution, 2-AG: 2-Arachidonoylglycerol, selective $C_{B}$, receptors agonist, Picrotoxin: GABA antagonist, CGP54626: GABAB antagonist, CB65: selective $C_{B}$ receptors agonist, $C G P 54626$ : $G A B A_{B}$ antagonist, Gaboxadol: $G_{A B A}$ agonist, SR141716A: selective $C B$, receptors antagonist, $A M 630$ : selective $C B 2$ receptors antagonist, Baclofen: $\mathrm{GABA}_{\mathrm{B}}$ agonist. 
CGP54626 (21ng) and (D) co-administration of CB65+CGP54626. In experiment 5, birds injected with (A) saline, (B) Gaboxadol (GABA, agonist, $0.2 \mu \mathrm{g}$ ), (C) SR141716A (selective $C B_{1}$ receptors antagonist, $6.25 \mu \mathrm{g}$ ) and (D) Gaboxadol+ SR141716A injected. In experiment 6, ICV injection of (A) saline, (B) Gaboxadol $(0.2 \mu \mathrm{g})$, (C) AM630 (selective $C_{2}$ receptors antagonist, $1.25 \mu \mathrm{g})$ and (D) co-injection of Gaboxadol+AM630 were applied. In trial 7, avian injected with $(A)$ saline, (B) baclofen (GABA $A_{B}$ agonist, $\left.0.2 \mu \mathrm{g}\right)$, (C) SR141716A $(6.25 \mu \mathrm{g})$ and $(D)$ baclofen+SR141716A. In experiment 8, (A) saline, (B) baclofen $\left(\mathrm{GABA}_{B}, 0.2 \mu \mathrm{g}\right)$, (C) AM630 $(1.25 \mu \mathrm{g})$ and $(\mathrm{D})$ co-injection of baclofen+AM630 used. The injection procedure is shown in Table 1. To find the possible interaction between these CBergic and GABAergic systems, effective and sub-effective doses of pharmacologic agents were administered to confront nullifying effects of the agents. In other words, when an effective dose of a system was administered, the sub-effective dose of the other system was considered. These doses of drugs were determined according to the previous studies (Jonaidi et al., 2002; Chen et al., 2006; Emadi et al., 2011; Novoseletsky et al., 2011; Alizadeh et al., 2015; Hassanpour et al., 2015).

\section{Statistical analysis}

Data is presented as mean \pm SEM (standard error of the mean). Cumulative food intake (as the percentage of body weight) was analyzed by repeated measure two-way analysis of variance (ANOVA) using SPSS 16.0 for Windows (SPSS, Inc., Chicago, IL, USA). For treatment showing a main effect by ANOVA, means were compared by Tukey-Kramer test. $\mathrm{p}<0.05$ was significant differences between treatments.

\section{RESULTS}

Effects and interactions of central CBergic and GABAergic systems on cumulative food intake in $\mathrm{FD}_{3}$ neonatal layer-type bird are shown in Figures 1-8.

In experiment 1, ICV injection of effective dose of $C B_{1}$ receptors agonist $(2-A G, 2 \mu g)$ significantly increased food intake (\% BW) in comparison with control group $[F(1,42)=67.02 ; p<0.001]$. Also, the ICV injection of sub effective dose of $\mathrm{GABA}_{A}$ antagonist Picrotoxin $(0.5 \mu \mathrm{g})$ had no effect on food intake compared to control group $[F(1,42)=0.01 ; p>0.05]$. Co-injection of $C B_{1}$ receptors agonist plus $G_{A B A}$ antagonist (Picrotoxin $+2-A G$ ) significantly decreased $C B$, receptors-induced hyperphagia [Time, $F(2,14)=$ 93.45, $p<0.001$; Picrotoxin $\times 2-A G$ interaction, $F(l, 42)=$ 48.95, $p<0.001$ ] [Fig. 1].

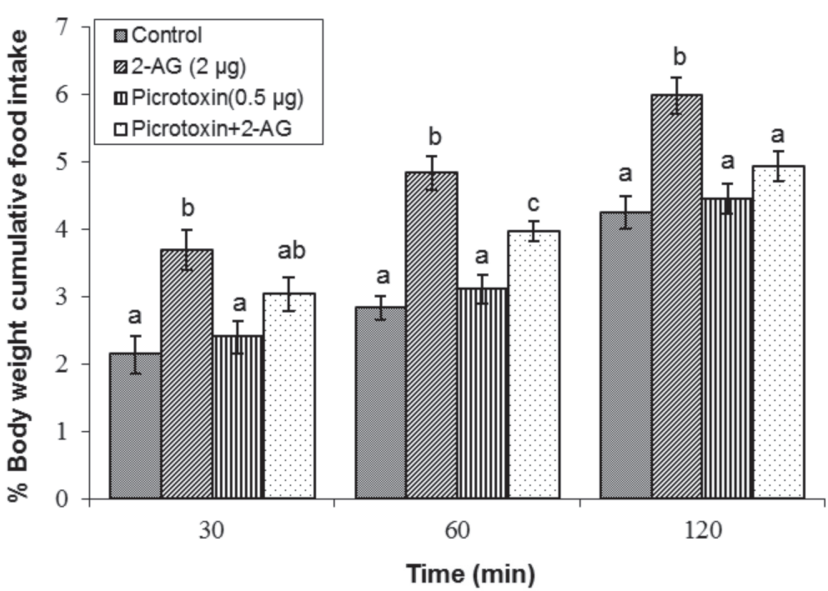

Figure 1 - Effect of ICV injection of 2-AG $(2 \mu \mathrm{g})$, Picrotoxin $(0.5 \mu \mathrm{g})$ and their combination on percent of body weight cumulative food intake in neonatal layer type chickens $(n=48)$. 2-AG: 2-Arachidonoylglycerol, selective $C B$ receptors agonist, Picrotoxin: GABA antagonist. Data are expressed as mean \pm SEM. $F$ and $P$ value for within and between subject factors are as follows: Time, $F(2,14)=93.45, p<0.001 ; 2-A G, F(l, 42)=67.02$ $p<0.001$; Picrotoxin, $F(\mid, 42)=0.01, p>0.05$; Picrotoxin $\times 2$-AG interaction, $F(\mid, 42)=$ 48.95, $p<0.001$. Different letters $(a, b$ and $c)$ indicate significant differences between treatments $(p<0.001)$. The average body weight for each group was as follows: control, $62.14 \mathrm{~g} ; 2-\mathrm{AG}, 61.71 \mathrm{~g}$; Picrotoxin, $61.48 \mathrm{~g} ;$ 2-AG + Picrotoxin, $62.83 \mathrm{~g}$.

In experiment 2, ICV injection of 2-AG, $(2 \mu \mathrm{g})$ had hyperphagic effect compared to control group in neonatal layers $[F(1,38)=39.51 ; p<0.001]$. Also, ICV injection of sub effective dose of $\mathrm{GABA}_{B}$ antagonist (CGP54626, 21ng) had no effect on food consumption $[F(1,38)=0.62 ; p>0.05]$. Co-injection of CGP54626 + 2-AG was not able to attenuated 2-AG-induced hyperphagia in neonatal layers [Time, $F(2,69)=112.04$, $\mathrm{p}<0.001$; CGP54626× 2-AG interaction, $F(l, 38)=0.08$, $\mathrm{p}>0.05]$ [Fig 2].

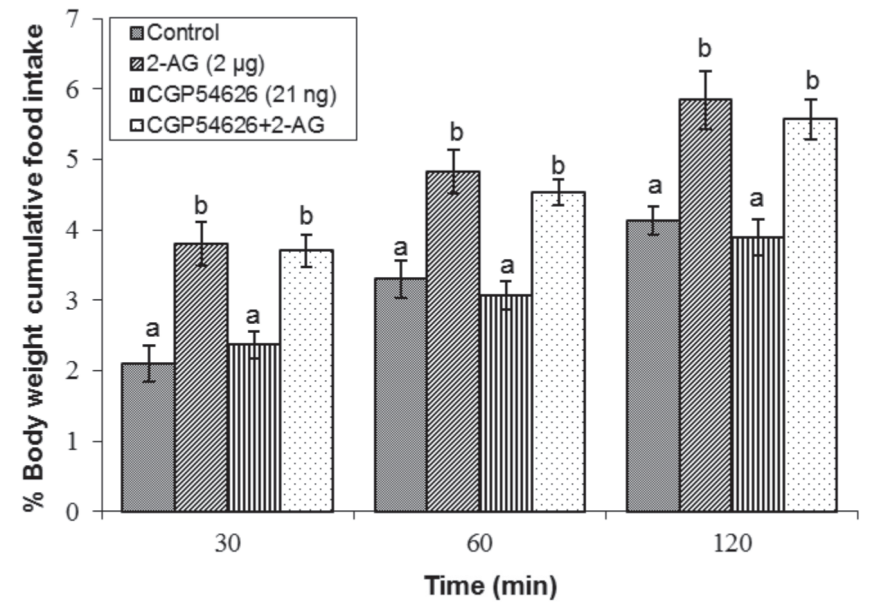

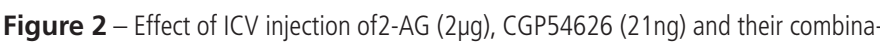
tion on percent of body weight cumulative food intake in neonatal layer type chickens $(n=48)$. 2-AG: 2-Arachidonoylglycerol, selective $C_{1}$ receptors agonist, CGP54626: GABA antagonist. Data are expressed as mean \pm SEM. $F$ and $P$ value for within and between subject factors are as follows: Time, $F(2,69)=112.04, p<0.001$; 2-AG $F(1,38)=39.51, p<0.001 ; C G P 54626, F(1,38)=0.62, p>0.05 ; C G P 54626 \times 2-A G$ interaction, $F(l, 38)=0.08, p>0.05$. Different letters ( $a$ and $b$ ) indicate significant differences between treatments $(p<0.001)$. The average body weight for each group was as follows: control, $64.26 \mathrm{~g} ;$ 2-AG, $63.92 \mathrm{~g}$; CGP54626, $63.19 \mathrm{~g} ;$ CGP54626 + 2-AG, $62.38 \mathrm{~g}$.

In experiment 3, ICV administration of CB65 $\left(\mathrm{CB}_{2}\right.$ receptors agonist, $1.25 \mu \mathrm{g}$ ) significantly increased food 
intake compared to control group $[F(1,54)=76.01$; $\mathrm{p}<0.001]$. ICV administration of Picrotoxin $(0.5 \mu \mathrm{g}) \mathrm{had}$ no effect on food intake compared to control group $[F(1,54)=0.08 ; p>0.05]$. Additionally, co-injection of Picrotoxin+CB65 was not able to fluctuate hyperphagic effect of $\mathrm{CB}_{2}$ receptors in neonatal layer-type chicks [Time, $F(2,81)=67.52, p<0.001$; Picrotoxin $\times$ CB65, $F(1,54)=1.36 ; p>0.05]$ [Fig 3].

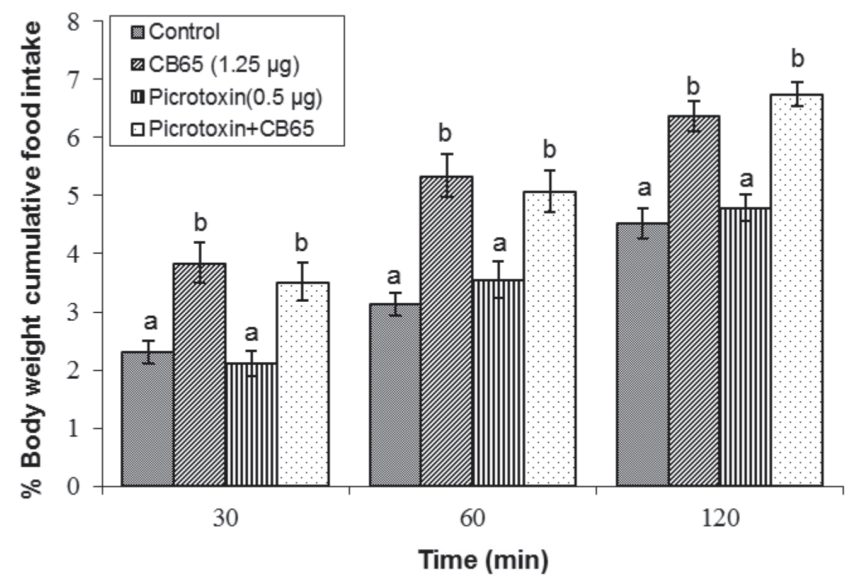

Figure 3 - Effect of ICV injection of CB65 (1.25 $\mu \mathrm{g})$, Picrotoxin $(0.5 \mu \mathrm{g})$ and their combination on percent of body weight cumulative food intake in neonatal layer type chickens $(n=48)$. CB65: selective $C_{2}$ receptors agonist, Picrotoxin: GABA antagonist. Data are expressed as mean $\pm S E M . F$ and $P$ value for within and between subject factors are as follows: Time, $F(2,81)=67.52, p<0.001 ; C B 65, F(1,54)=76.01, p<0.001$; Picrotoxin, $F(1,54)=0.08, p>0.05$; Picrotoxin $\times$ CB65interaction, $F(1,54)=1.36 ; p>0.05$. Different letters $(a$ and $b)$ indicate significant differences between treatments $(p<0.001)$. The average body weight for each group was as follows: control, $63.41 \mathrm{~g}$; CB65, $63.75 \mathrm{~g}$; Picrotoxin, $62.74 \mathrm{~g}$; CB65 + Picrotoxin, $62.51 \mathrm{~g}$.

In experiment 4, ICV injection of CB65 $(1.25 \mu \mathrm{g})$ significantly amplified feeding behavior in neonatal layer-type chicks in comparison with control group $[F(1,26)=47.15 ; p<0.001]$. ICV injection of sub effective dose of GABA $_{\mathrm{B}}$ antagonist, CGP54626 (21ng), had no role on food consumption compared to control group $[F(1,26)=0.49 ; p>0.05]$. Also, their combination (CGP54626+CB65) had no effect on $\mathrm{CB}_{2}$ receptors agonist-induced hyperphagia [Time, $F(2,55)=124.13$, $p<0.001$; CGP54626x CB65interaction $F(1,26)=1.27$; $\mathrm{p}>0.05$ ] [Fig 4].

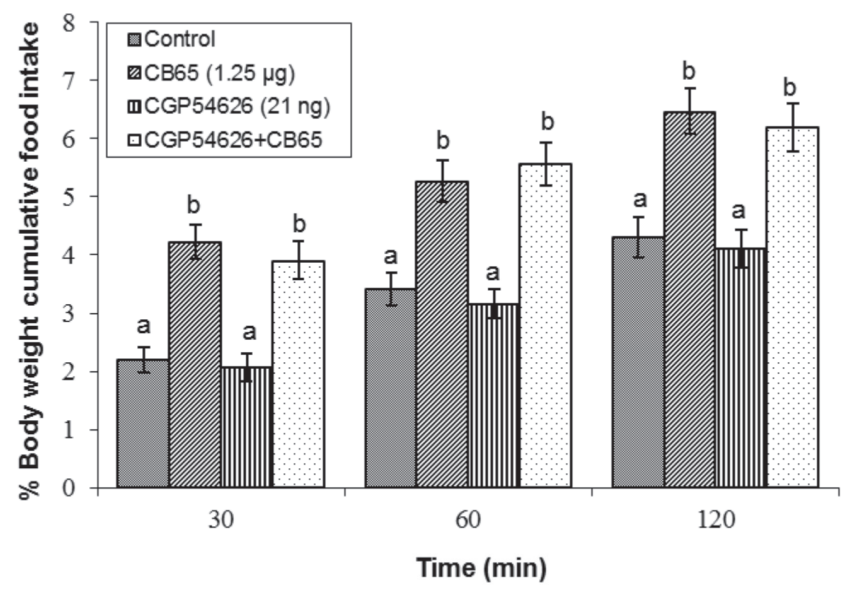

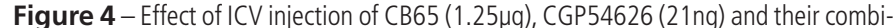
nation on percent of body weight cumulative food intake in neonatal layer type chickens $(n=48)$. CB65: selective $C_{B}$ receptors agonist, CGP54626: $G_{A B A}$ antagonist. Data are expressed as mean \pm SEM. $F$ and $P$ value for within and between subject factors are as follows: Time, $F(2,55)=124.13, p<0.001 ; C B 65, F(1,26)=47.15, p<0.001 ;$ CGP54626, $F(1,26)=0.49, p>0.05 ;$ CGP54626 $\times$ CB65interaction, $F(1,26)=1.27 ; p>0.05$. Different letters $(a$ and $b)$ indicate significant differences between treatments $(p<0.001)$. The average body weight for each group was as follows: control, $61.43 \mathrm{~g}$; CB65, $62.04 \mathrm{~g}$; CGP54626, 63.27 g; CB65 + CGP54626, $62.17 \mathrm{~g}$.

In experiment 5, ICV injection of effective dose of $\mathrm{GABA}_{\mathrm{A}}$ agonist, (Gaboxadol, $0.2 \mu \mathrm{g}$ ) significantly increased cumulative food intake compared to control group $[F(1,53)=87.04 ; p<0.001]$. ICV injection of sub effective dose of selective $C B$, receptors antagonist, (SR141716A, 6.25 $\mu \mathrm{g}$ ) had no effect on food intake $[F(1,53)=0.31 ; p>0.05]$. Also, co-administration of SR141716A + Gaboxadol significantly decreased Gaboxadol-induced hyperphagia at 60 and $120 \mathrm{~min}$ after the injection [Time, $F(2,79)=56.27, p<0.001$; SR141716A $\times$ Gaboxadol interaction, $F(1,53)=65.93$; $\mathrm{p}<0.001$ ] [Fig 5].

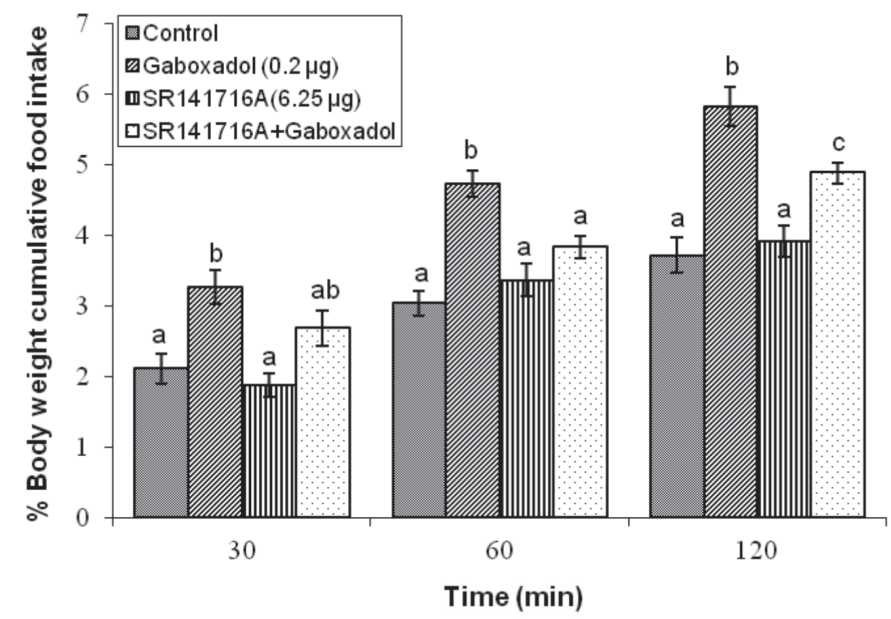

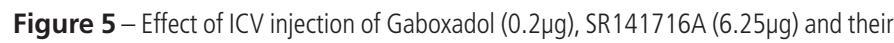
combination on percent of body weight cumulative food intake in neonatal layer type chickens ( $n=48)$. Gaboxadol: GABA agonist, SR141716A: selective $C B$, receptors antagonist. Data are expressed as mean \pm SEM. F and $P$ value for within and between subject factors are as follows: Time, $F(2,79)=56.27, p<0.001$; Gaboxadol, $F(1,53)=87.04$, $p<0.001 ;$ SR141716A, $F(1,53)=0.31, p>0.05 ;$ SR141716A $\times$ Gaboxadol interaction $F(1,53)=65.93 ; p<0.001$. Different letters $(a, b$ and $c)$ indicate significant differences between treatments $(p<0.001)$. The average body weight for each group was as follows: control, 64.26 g; Gaboxadol, 64.74 g; SR141716A, 64.06 g; Gaboxadol + SR141716A, $63.81 \mathrm{~g}$.

In experiment 6, ICV injection of Gaboxadol at dose of $0.2 \mu \mathrm{g}$ amplified food consumption $[F(1,21)=38.12 ; p<0.001]$ but ICV injection of sub effective dose of selective $C B_{2}$ receptors antagonist (AM630, 1.25 $\mu \mathrm{g}$ ) had no effect on feeding behavior in neonatal layer-type chicks $[F(1,21)=1.02 ; p>0.05]$. Co-injection of AM630+ Gaboxadol had no effect on $\mathrm{GABA}_{A}$ receptors-induced hyperphagia [Time, $F(2,17)=48.91, \quad p<0.001 ; \quad A M 630 \times$ Gaboxadol interaction, $F(1,21)=2.37 ; p>0.05$ ] [Fig 6]. 
Zendehdel M, Tirgari F, Shohre B, Deldar H, Hassanpour S

\section{Involvement of Gaba and Cannabinoid Receptors in Central Food Intake Regulation in Neonatal Layer Chicks: Role of $C B_{1}$ and $G A B A_{A}$ Receptors}

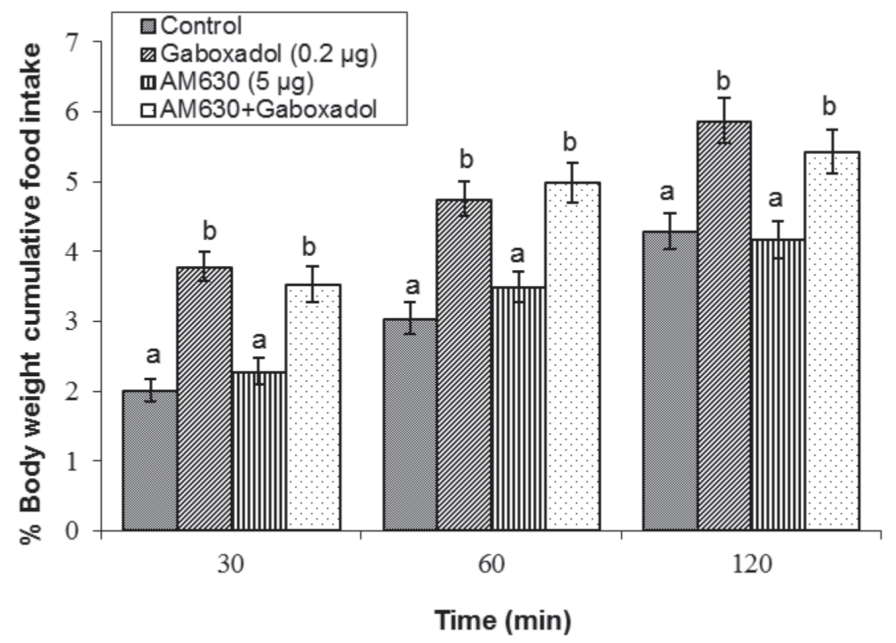

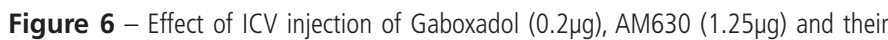
combination on percent of body weight cumulative food intake in neonatal layer type chickens ( $n=48)$. Gaboxadol: GABA agonist, $A M 630$ : selective $C_{2}$ receptors antagonist. Data are expressed as mean $\pm S E M$. $F$ and $P$ value for within and between subject factors are as follows: Time, $F(2,17)=48.91, p<0.001$; Gaboxadol, $F(1,21)=38.12, p<0.001$; AM630, $F(1,21)=1.02, p>0.05 ;$ AM630 $\times$ Gaboxadol interaction, $F(1,21)=2.37$; $p>0.05$. Different letters $(a$ and $b$ ) indicate significant differences between treatments $(p<0.001)$. The average body weight for each group was as follows: control, $62.35 \mathrm{~g}$; Gaboxadol, 61.96 g; AM630, $61.47 \mathrm{~g}$; Gaboxadol + AM630, $62.94 \mathrm{~g}$.

In experiment 7, ICV injection of effective dose of $\mathrm{GABA}_{B}$ agonist (baclofen, $0.2 \mu \mathrm{g}$ ) significantly improved food intake in comparison to the control group $[F(1,31)=46.73 ; p<0.001]$. ICV injection of selective $C_{1}$ receptors antagonist (SR141716A, $6.25 \mu \mathrm{g}$ ) had no effect on food intake in neonatal layertype chicks $[F(1,31)=0.09 ; p>0.05]$. Co-administration of SR141716A + baclofen had no effect on baclofeninduced hyperphagia [Time, $F(2,83)=102.17, p<0.001$; SR141716A $\times$ baclofen interaction, $F(1,31)=0.04$; p>0.05] [Fig 7].

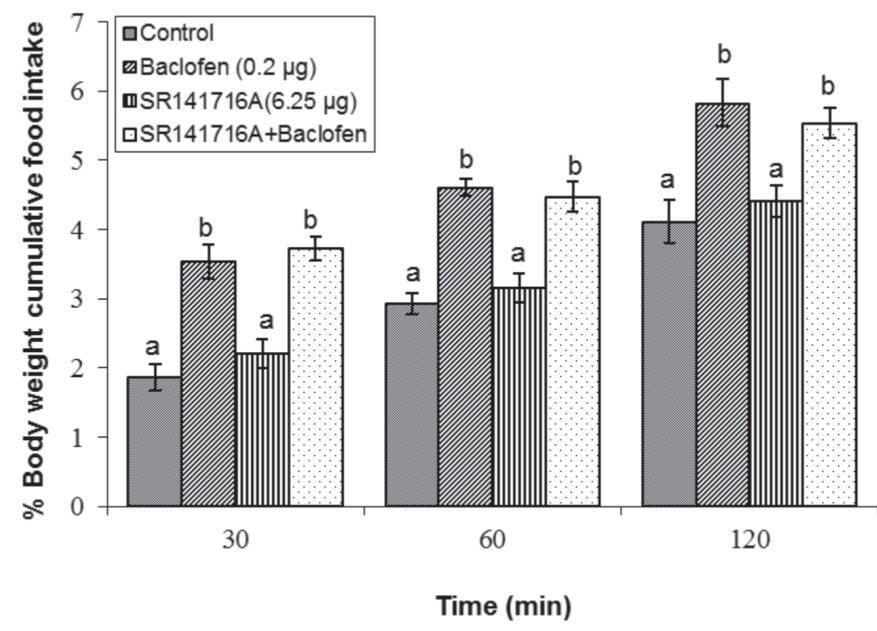

Figure 7 - Effect of ICV injection of Baclofen $(0.2 \mu \mathrm{g})$, SR141716A $(6.25 \mu \mathrm{g})$ and their combination on percent of body weight cumulative food intake in neonatal layer type chickens ( $n=48)$. Baclofen: $G A B A_{B}$ agonist, SR141716A: selective $C B$, receptors antagonist. Data are expressed as mean \pm SEM. $F$ and $P$ value for within and between subject factors are as follows: Time, $F(2,83)=102.17, p<0.001$; Baclofen, $F(1,31)=46.73$, $p<0.001 ;$ SR141716A, $F(1,31)=0.09, p>0.05 ; S R 141716 \mathrm{~A} \times$ Baclofen interaction, $F(1,31)=0.04 ; p>0.05$. Different letters ( $a$ and $b$ ) indicate significant differences between treatments $(p<0.001)$. The average body weight for each group was as follows: control $64.11 \mathrm{~g}$; baclofen, 64.26 g; SR141716A, $63.21 \mathrm{~g}$; Baclofen + SR141716A, $62.75 \mathrm{~g}$.

In experiment $8, \mathrm{ICV}$ injection of baclofen $(0.2 \mu \mathrm{g})$ showed hyperphagic effect $[F(1,46)=63.01 ; p<0.001]$; but ICV injection of $A M 630$ (selective $C_{2}$ receptors antagonist, $1.25 \mu \mathrm{g}$ ) had no effect on feeding behavior $[F(1,46)=0.06 ; p>0.05]$. Also, the combined injection of baclofen + AM630 was not able to fluctuate $G_{A B A}$ receptors-induced food intake in neonatal layer-type chicks [Time, $F(2,65)=70.31, p<0.001 ; A M 630 \times$ Baclofen interaction, $F(1,46)=0.83 ; p>0.05$ ] [Fig 8].

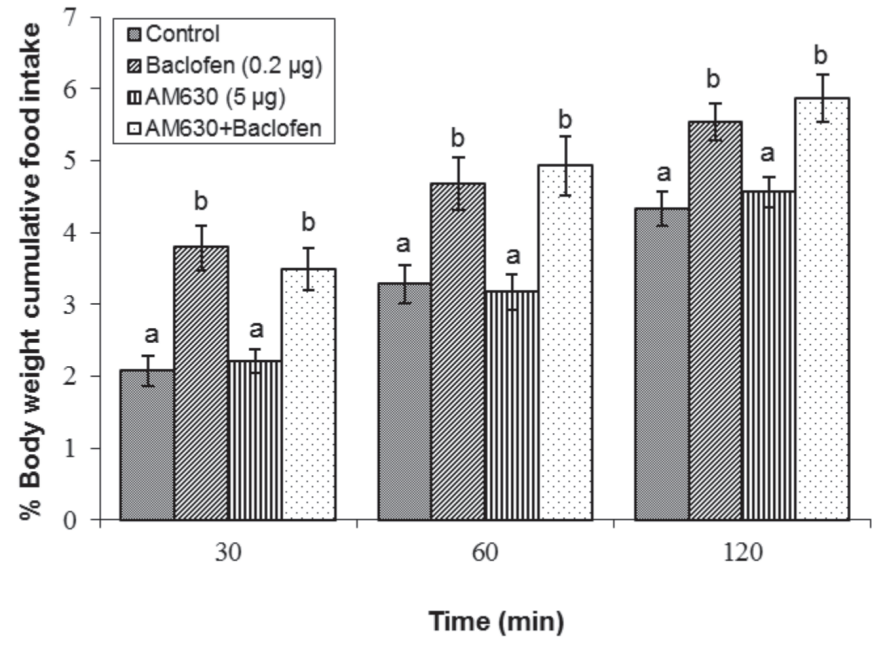

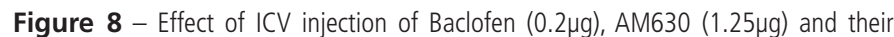
combination on percent of body weight cumulative food intake in neonatal layer type chickens ( $n=48$ ). Baclofen: $G A B A_{8}$ agonist, $A M 630$ (selective $C B$ receptors antagonist). Data are expressed as mean \pm SEM. F and $P$ value for within and between subject factors are as follows: Time, $F(2,65)=70.31, p<0.001$; Baclofen, $F(1,46)=63.01, p<0.001$ AM630, $F(1,46)=0.06, p>0.05 ;$ AM630 $\times$ Baclofen interaction, $F(1,46)=0.83 ; p>0.05$ Different letters $(a$ and $b)$ indicate significant differences between treatments $(p<0.001)$ The average body weight for each group was as follows: control, $61.48 \mathrm{~g}$; baclofen, $61.92 \mathrm{~g}$; AM630, 63.19 g; baclofen + AM630, $62.38 \mathrm{~g}$

\section{DISCUSSION}

So far, numerous researches were done to investigate the role of neurotransmitters on appetite regulation in mammals, but aspects of food intake regulation in avian are still unclear (Zendehdel \& Hassanpour 2014). To the best of our knowledge, there are no studies describing the interaction between CBergic and GABAergic systems on food intake in $\mathrm{FD}_{3}$ neonatal layer-type chickens. According to the results, ICV injection of $\mathrm{CB}_{1}$ and $\mathrm{CB}_{2}$ agonists amplified food consumption in layertype chicks which was similar to mammals (Chen et al., 2006; Wiley et al., 2012) and recent studies on layertype chicks (Alizadeh et al., 2015; Hassanpour et al., 2015). However, these results were dissimilar compared to broilers which only $\mathrm{CB}_{2}$ receptors were responsible for feeding (Emadi et al., 2011; Novoseletsky et al., 2011). The ECBs is an important modulator in the central and peripheral regulation of energy and 
metabolism (Bellocchio et al., 2013). Broilers are genetically selected for rapid muscle and body weight gain while layer has indirectly been selected for slow growth and low body weight. So, presumably, genetic selection altered chicken's brain neurological pathways associated with food intake (Denbow 1994; Richards 2003). It is a hypothetical effect of ECBs on appetite regulation which mediates at two levels. First, ECBs reinforces the motivation to find and eating, possibly via interaction with the mesolimbic pathways involved in reward mechanisms. Second, it activated 'on demand' in the hypothalamus after short-term food deprivation, then transiently regulates the action of the other orexigenic and anorectic neurotransmitters. The dual action hypothesis in mesolimbic and hypothalamic regions revealed by the finding that injection of ECBs into these brain areas provoke food intake in rodents (Di Marzo \& Matias, 2005).

Based on the results, ICV injection of $\mathrm{GABA}_{A}$ and $G A B A_{B}$ receptors agonists increased food intake in neonatal layer-type chicks. These results were in agreement with observation in rats (Di Marzo et al., 2004), broilers (Jonaidi et al., 2002), turkeys (Denbow, 1991) sheep (Seone et al., 1984) and pigs (Baldwin et al., 1990). Regarding the site of action of GABA, with rats and sheep suggest GABA might alter food intake on some intra hypothalamic or extra-hypothalamic structures (Jonaidi et al., 2002). Several possible mechanisms introduced the mechanism of action of GABA. For example, it may inhibit the satiety centers e.g. ventromedial hypothalamus $(\mathrm{VMH})$. GABA may act via dis-inhibition of the brain feeding centers by inhibitory GABAergic projection from the medial accumbens to the lateral hypothalamus (LH). Finally, GABA can exert orexigenic effect via a direct excitatory effect in some regions of the brain including the hypothalamus (Jonaidi et al., 2002).

As observed in this study, hyperphagic effects of 2-AG ( $C B_{1}$ receptors agonist) attenuated by coinjection of $2-A G+$ Picrotoxin $\left(G A B A_{A}\right.$ receptors antagonist). $C B_{1}$ receptors control the activity of many neurotransmitter systems involved in central regulation of food intake (Pagotto et al., 2006). In the CNS, CB 1 is predominantly expressed presynaptically, modulating the release of neurotransmitters, such as GABA, dopamine, noradrenaline, glutamate and serotonin (Cota et al., 2003). These data showed there might be an interaction between central CBergic and $G A B A e r g i c$ systems via $C B_{1}$ and $G A B A_{A}$ receptors. The broad distribution of $C B_{1}$ receptors in the CNS, along with its modulatory role on other neurotransmitter systems, complicates the mechanisms underlying its effect on food intake regulation (Rey et al., 2012).

Retrograde signaling by ECBs released from depolarized postsynaptic neurons inhibits presynaptic GABA release in the lateral hypothalamus and arcuate nucleus (ARC) (Di Marzo et al., 2004). The ARC plays a crucial role in the integration of signals regulating appetite. The ARC is accessible to circulating signals of energy balance via the median eminence, this is not protected by the blood-brain barrier. In the ARC two types of neurons identified which integrates signals of nutritional status and influence energy homeostasis: pro-opiomelanocortin (POMC) and cocaine and amphetamine regulated transcript (CART) which are anorexigenic neuropeptides while another neuronal circuit stimulates feed intake via neuropeptide $Y$ (NPY) and agoutirelated protein (AgRP) (Zendehdel \& Hassanpour 2014). The AgRP, POMC and NPY contain the GABA $R$ alpha (3) subunit in the ventromedial and ventrolateral part of ARC (Jonaidi et al., 2002). ECBs impress their hyperphagic effect by modulating POMC neurons via $C B_{1}$ receptors in the $A R C$ (Hentges et al., 2005). Also, ICV injection of the $C B_{1}$ receptors agonist increases NPY levels (D'Addario et al., 2014). A strong indication exists for $C B_{1}$ receptors on modulating appetite by enhancement of NPY (Cota et al., 2003). One potential target for cannabinoids in the arcuate nucleus is NPY/ AgRP /GABA neurons (Menzies et al., 2010). This is most likely a direct inhibitory effect on spontaneous release mediated via pre-synaptic $C_{1}$ receptors on NPY/AgRP /GABA neurons or other GABAergic terminals in the explanation. It is reported that $C B$, receptor mRNA are not expressed by arcuate NPY/ AgRP /GABA neurons and target probably underlies the direct effect (Menzies et al., 2010). CB receptors are expressed in presynaptic terminals of excitatory neurons (Sharkey et al., 2014). Functionally, $\mathrm{GABA}_{A}$ receptors seem to be located both pre- and post-synapses (Tellez et al., 2012). GABA $A_{A}$ receptors are ionotropic receptors which couple to a $\mathrm{Cl}^{-}$ionophore (Jonaidi et al., 2012). ECBs synthesized in postsynaptic neurons and binds to $C B$ receptors on the presynaptic membrane. These receptors belong to $G$ protein, inhibits $\mathrm{Ca}^{2+}$ influx which decreases the release of other neurotransmitters (Williams and Kirkham 2002). CBs modulate GABA release in a variety of CNS regions, including the hippocampus, basal ganglia, cerebellum, and brainstem. Activation of $C_{1}$ receptors modulates the release of GABA in the brain. However, minute information exists about the mechanism behind the interaction of $C B_{1}$ with $G_{A B A}$ receptors. 
Anatomical investigations have shown high levels of $C B$ receptor immune reactivity and mRNA associated with GABAergic neurons. CBs modulate GABA release by a presynaptic mechanism. Presumably, effect of $C B_{1}$ receptors on $\mathrm{GABA}_{A}$ release is mediated via inhibition of presynaptic $\mathrm{Ca}^{2+}$ channels (Irving et al., 2002).

To the best of our knowledge, $C B$ receptors mRNA expressed by POMC neurons and $C B s$ directly inhibit arcuate POMC neurons. In turn, POMC neurons inhibit GABA release from NPY/AgRP neurons (Menzies et al., 2010). As observed in this study, the hyperphagic effect of $C B$, receptors diminished by $G A B A_{A}$ receptors antagonist (experiment 1). For instance, hyperphagic effects of $G A B A$ receptors minimized by $C B_{1}$ receptors antagonist (experiment 5). Presumably, ECBs, by inhibition of the hypothalamic POMC, leads to increasing GABA release in the CNS of neonatal layer-type chicken. So, it seems both CBergic and GABAergic systems impress their hyperphagic effects via $C B_{1}$ receptors in neonatal layer-type chicken. Also, perhaps CBergic and GABAergic systems interact with other systems such as opioidergic system (Menzies et al., 2010).

Most research on central food intake regulation was done on rat models because few investigations were in avian. These results can use as base information on central appetite regulation in layer-type chicken. Finally, the authors recommend merit investigation needed to find direct cellular and molecular signaling pathways of CBergic and GABAergic mechanism with other neurotransmitters in the physiology of eating behavior in poultry.

\section{CONFLICT OF INTEREST}

Authors declare that they have no conflict of interest.

\section{INFORMED CONSENT}

This manuscript does not contain any studies with human subjects performed by any of the authors.

\section{HUMAN AND ANIMAL RIGHTS}

All experiments executed according to the Guide for the Care and Use of Laboratory Animals and approved by the institutional animal ethics committee.

\section{REFERENCES}

Alimohammadi S, Zendehdel M, Babapour V. Modulation of opioid-induced feeding behavior by endogenous nitric oxide in neonatal layer-type chicks. Veterinary Research Communications 2015;39:105-113.
Alizadeh A, Zendehdel M, Babapour V, Charkhkar S, Hassanpour S. Role of cannabinoidergic system on food intake in neonatal layer-type chicken. Veterinary Research Communications 2015;39:151-157.

Baldwin BA, Ebenezer IS, De La Riva C. Effects of intracerebroventricular injection of muscimol or GABA on operant feeding in pigs. Physiology \& Behavior 1990:48:417-421.

Bellocchio L, Soria-Gómez E, Quarta C, Metna-Laurent M, Cardinal P, Binder $E$, et al. Activation of the sympathetic nervous system mediates hypophagic and anxiety-like effects of $C B$, receptor blockade. PANS 2012;110(12):4786-4791

Blevins JE, Stanley BG, Reidelberger RD. DMSO as a vehicle for central injections:tests with feeding elicited by norepinephrine injected into the paraventricular nucleus. Pharmacology, Biochemistry, and Behavior $2002 ; 71: 277-282$

Bonaventura MM, Crivello M, Ferreira ML, Repetto M, Cymeryng C, Libertun $C$, et al. Effects of GABAB receptor agonists and antagonists on glycemia regulation in mice. European Journal of Pharmacology 2012;677:188-196.

Chen RZ, Frassetto A, Fong TM. Effects of the CB, cannabinoid receptor inverse agonist $A M 251$ on food intake and body weight in mice lacking l-opioid receptors. Brain Research 2006;1108:176-178.

Cota D, Marsicano G, Lutz B, Vicennati V, Stalla GK, Pasquali R, et al. Endogenous cannabinoid system as a modulator of food intake. International Journal of Obesity 2003;27:289-301.

D’Addario C, Micioni Di Bonaventura MV, Puccia M, Romano A, Gaetani S, Ciccocioppo R, et al. Endocannabinoid signaling and food addiction. Neuroscience \& Biobehavioral Reviews 2014;47:203-224

Davis JL, Masuoka DT, Gerbrandt LK, Cherkin A. Autoradiographic distribution of L-proline in chicks after intracerebral injection. Physiology \& Behavior 1979;22:693-695

Denbow DM. Induction of food intake by a GABAergic mechanism in the turkey. Physiology \& Behavior 1991;49:485-488

Denbow DM. Peripheral regulation of food intake in poultry. Journal of Nutrition 1994;124:1349S-1354S.

Di Marzo V, Bifulco F, De Petrocellis L. The endocannabinoid system and it's the rapeutic exploitation. Nature Reviews Drug Discovery 2004;3:771784.

Di Marzo V, Matias I. Endocannabinoid control of food intake and energy balance. Nature Neuroscience 2005:8(5):585-589.

Ebenezer IS. The effect of intracerebroventricular administration of baclofen on food intake in rats, Neuro Report 1990;1:73-76.

Emadi $L$, Jonaidi $H$, Hosseini Amir Abad $E$. The role of central $C B_{2}$ cannabinoid receptors on food intake in neonatal chicks. Journal of Comparative Physiology A 2011;197:1143-1147

Furuse M, Matsumoto M, Saito N, Sugahara K, Hasegawa S. The central corticotropin-releasing factor and glucagon-like peptide-1 in food intake of the neonatal chick. European Journal of Pharmacology 1997;339:211-214.

Hassanpour S, Zendehdel M, Babapour V, Charkhkar S. Endocannabinoid and nitric oxide interaction mediates food intake in neonatal chicken. British Poultry Science 2015;56(4):443-451.

Hentges ST, Low MJ, Williams JT. Differential regulation of synaptic inputs by constitutively released endocannabinoids and exogenous cannabinoids. Journal of Neuroscience 2005;25:9746-9751. 
Honda K. Glucagon-related peptides and the regulation of food intake in chickens. Animal Science Journal 2016. DOI:10.1111/asj.12619.

Irving AJ, Rae MG, Coutts AA. Cannabinoids on the Brain. Scientific World Journal 2002;2:632-648.

Jonaidi H, Abbassi L, Yaghoobi MM, Kaiya H, Denbow DM, Kamali Y, et al. The role of GABAergic system on the inhibitory effect of ghrelin on food intake in neonatal chicks Neuroscience Letters 2012;520:82-86.

Jonaidi $\mathrm{H}$, Babapour $\mathrm{V}$, Denbow DM. GABAergic control of food intake in the meat-type chickens. Physiology \& Behavior 2002;76:465- 468

Kangas BD, Delatte MS, Vemuri VK, Thakur GA, Nikas SP, Subramanian KV, et al. Cannabinoid discrimination and antagonism by CB1 neutral and inverse agonist antagonists. Journal of Pharmacology and Experimental Therapeutics 2013;344:56-567.

Menzies JRW, Ludwig M, Leng G. Direct and indirect effects of cannabinoids on in vitro GABA release in the rat arcuate nucleus. Journal of Neuroendocrinology 2010;22:585-592.

Novoseletsky N, Nussinovitch A, Friedman-Einat M. Attenuation of food intake in chicks by an inverse agonist of cannabinoid receptor 1 administered by either injection or ingestion in hydrocolloid carriers. General and Comparative Endocrinology 2011;170:522-527.

Olanrewaju HA, Thaxton JP, Dozier WA, Purswell J, Roush WB, Branton SL. A review of lighting programs for broiler production. International Journal of Poultry Science 2006;5(4):301-308.

Onaivi ES, Carpio O, Ishiguro H, Schanz N, Uhl GR, Benno R. Behavioral effects of $\mathrm{CB}_{2}$ cannabinoid receptor activation and its influence on food and alcohol consumption. Annals of the New York Academy of Sciences 2008; 1139:426-433.

Pagotto U, Marsicano G, Cota D, Lutz B, Pasquali R. The emerging role of the endocannabinoid system in endocrine regulation and energy balance. Endocrine Reviews 2006;27(1):73-100.

Pu S, Jain MR, Horvath TL, Diano S, Kalra PS, Kalra SP. Interactions between neuropeptide $Y$ and gamma-aminobutyric acid in stimulation of feeding:a morphological and pharmacological analysis. Endocrinology 1999;140:933-940.

Qi W, Ding D, Salvi RJ. Cytotoxic effects of dimethyl sulphoxide (DMSO) on cochlear organotypic cultures. Hearing research 2008;236:52-60.

Rey AA, Purrio M, Viveros MP, Lutz B. Biphasic Effects of Cannabinoids in Anxiety Responses: $C_{1}$ and $G_{1} A B A_{B}$ Receptors in the Balance of GABAergic and Glutamatergic Neurotransmission. Neuropsychopharmacology 2012;37:2624-2634.

Richards MP. Genetic regulation of feed intake and energy balance in poultry. Poultry Science 2003;82:907-916.
Saito ES, Kaiya H, Tachibana T, Tomonaga S, Denbow DM, Kangawa K et al. Inhibitory effect of ghrelin on food intake is mediated by the corticotropin-releasing factor system in neonatal chicks. Regulatory Peptides 2005;125:201-208.

Seone JR, Dumont F, Girard CL, Bedard L, Matte JJ. Effects of intraventricular injections of gamma-aminobutyric acid and related substances on feeding behavior in satiated sheep. Canadian Journal of Physiology and Pharmacology 1984;62:1296-1209.

Sharkey KA, Darmani NA, Parker LA. Regulation of nausea and vomiting by cannabinoids and the endocannabinoid system. European Journal of Pharmacology 2014;722:134-146.

Stratford TR, Wirtshafter D. Injections of muscimol into the paraventricular thalamic nucleus, but not mediodorsal thalamic nuclei, induce feeding in rats. Brain Research 2013;1490:128-133

Tajalli S, Jonaidi H, Abbasnejad M, Denbow DM. Interaction between nociceptin/orphanin FQ (N/OFQ) and GABA in response to feeding. Physiology \& Behavior 2006;89:410-413.

Tellez R, Gómez-Víquez L, Meneses A. GABA, glutamate, dopamine and serotonin transporters expression on memory formation and amnesia. Neurobiology of Learning and Memory 2012;97:189-201.

Van Tienhoven A, Juhasz LP. The chicken telencephalon, diencephalon and mesencephalon in sterotaxic coordinates. Journal of Comparative Neurology 1962;118:185-197

Volkow ND, Wang GJ, Baler RD. Reward, dopamine and the control of food intake:Implications for obesity. Trends in Cognitive Sciences 2011;15(1):37-46

Wiley JL, Marusich JA, Zhang Y, Fulp A, Maitra R, Thomas BF, et al. Structural analogs of pyrazole and sulfonamide cannabinoids:effects on acute food intake in mice. European Journal of Pharmacology 2012;695:6270.

Williams CM, Kirkham TC. Reversal of $\triangle 9$-THC hyperphagia by SR141716 and naloxone but not dexfenfluramine. Pharmacology Biochemistry and Behavior 2002;71:333-340.

Zendehdel $\mathrm{M}$, Babapour $\mathrm{V}$, Jonaidi $\mathrm{H}$. Effects of central histamine receptors blockade on GABA (A) agonist-induced food intake in broiler cockerels. Pakistan Journal of Biological Sciences 2008;11(3):416-421.

Zendehdel M, Baghbanzadeh A, Babapour V, Cheraghi J. The effects of bicuculline and muscimol on glutamate-induced feeding behaviour in broiler cockerels. Journal of Comparative Physiology A 2009;195:715720.

Zendehdel M, Hassanpour S. Ghrelin-induced hypophagia is mediated by the $\beta 2$ adrenergic receptor in chicken. The Journal of Physiological Sciences 2014;64:383-391. 
